\title{
Effect of Cnidoscolus aconitifolius Leaf Extract on Selected Renal Parameters and Hematological Indices of Carbon Tetrachloride Induced Toxic Rats
}

\author{
Iwu C. C., Akwukwaegbu P. I. , Ikewuchi C. C. \\ Department of Biochemistry, University of Port Harcourt, Nigeria
}

Received March 16, 2020; Revised April 6, 2020; Accepted April 19, 2020

Copyright@2020 by authors, all rights reserved. Authors agree that this article remains permanently open access under the terms of the Creative Commons Attribution License 4.0 International License

\begin{abstract}
Effect of Cnidoscolus aconitifolius leaf extract on selected renal parameters and hematological indices of carbon tetrachloride $\left(\mathrm{CCl}_{4}\right)$ induced toxic rats was investigated using standard analytical methods. Forty-two (42) wistar rats weighing 91-185g was used for this study. The rats were divided into 7 groups of 6 rats each and allowed to acclimatize for one week with food and water ad libitum. Carbon tetrachloride was prepared in the ratio of 1:5 (v:v) in olive oil and administered subcutaneously at $0.17 \mathrm{~mL} / \mathrm{kg}$ body weight on the first day after acclimatization. Group I received normal feed and water only, group II received $\mathrm{CCl}_{4}$ only, group III received olive oil only, groups IV, V and VI received $50 \mathrm{mg} / \mathrm{kgbw}$, $75 \mathrm{mg} / \mathrm{kgbw}$ and $100 \mathrm{mg} / \mathrm{kgbw}$ oral dose of C. aconitifolius respectively in addition to $\mathrm{CCl}_{4}$ while group VII received vitamin $\mathrm{C}$ plus $\mathrm{CCl}_{4}$. After oral administration for twenty-one days, the rats were painlessly sacrificed; plasma and blood were collected for renal and hematological analyses respectively. Results showed that $\mathrm{CCl}_{4}$ increased $\mathrm{Ca}, \mathrm{Na}, \mathrm{K}$ and decreased RBC, PCV, $\mathrm{Hb}$ and platelet number of rats induced, however oral administration of C. aconitifolius significantly decreased; $\mathrm{Ca}$ and $\mathrm{Na}$ at $50 \mathrm{mg} / \mathrm{kgbw}, \mathrm{K}$ in a dose-dependent pattern and significantly increased RBC, PCV, Hb and platelet number at all doses. This study has shown that the leaf extract of Cnidoscolus aconitifolius had a dose-dependent positive effect on the hematological indices as well as the potential to ameliorate kidney parameters of $\mathrm{CCl}_{4}$ treated wistar rats at the given concentrations.
\end{abstract}

Keywords Cnidoscolus aconitifolius, Renal Parameters, Hematological Indices, Carbon Tetrachloride

\section{Introduction}

Cnidoscolus aconitifolius is a native of Central America but seen in tropical and subtropical regions like India and Africa [1]. It belongs to the family of Euphorbiaceae and commonly referred to as "hospital too far" or "Catholic vegetable" in southern Nigeria [2, 3]. In southern Nigeria, C. aconitifolius is majorly utilized as fencing material [4]. Traditionally, the leaves of $C$. aconitifolius is utilized as tonic by some herbalist, as it is presumed to treat anaemia, malaria, diabetes, dermal infections and cardiovascular diseases [5, 6]. According to [7], C. aconitifolius leaf has high concentration of potassium, phosphorus, calcium, sodium, zinc, iron and magnesium minerals. The high composition of minerals in C. aconitifolius makes this vegetable relevant in health maintenance $[8,9,10]$.

Extract from Cnidoscolus aconitifolious aids red blood cell formation and maintains stability especially protein-energy malnourished patients [11]. This is very essential for managing sickle cell disease and malaria parasite infection as both diseases are rooted to the red cells. According to studies, the ability of Cnidoscolus aconitifolius extract to boost erythrocytes may be due to its vitamin and mineral contents as it was established that zinc, vitamin A, ascorbic acid and metal ions regulated damaged growth and immune functions that occurred from malaria illness [12, 13, 14, 15, 16, 17].

\section{Methodology}

\subsection{Extraction of the Leaves}

Cnidoscolus aconitifolius leaves were collected fresh, washed to get rid of dirt and dried. The leaves were crushed with a mortar and pestle and aqueous extraction done according to [18]. The crude extract was subjected to evaporation using a water bath before freeze-drying.

\subsection{Experimental Design}

The animals (42 wistar rats) weighing 91-185g, used in 
this work were purchased from the animal house of the Department of Physiology, University of Port Harcourt. The rats were divided into 7 groups of 6 rats each and allowed to acclimatize for one week. Water and food were given to the rats ad libitum. The groupings and dosage of administration was as shown in Table 1. Carbon tetrachloride was prepared in the ratio of 1:5 (v:v) in olive oil and administered subcutaneously at $0.17 \mathrm{~mL} / \mathrm{kg}$ body weight on the first day after acclimatization. The method of [19] was adopted for dosage administration of $\mathrm{CCl}_{4}$. Twenty-four hours after $\mathrm{CCl}_{4}$ administration, treatment with the leaf extract commenced. Administration of the extract and antioxidant (Vitamin C) was done orally on daily basis for twenty-one days as adopted from [20] and [21]. The rats were grouped as Table 1 .

After oral administration for twenty-one days, the six rats per group were fasted over night, weighed and anaesthetized by exposure to chloroform. The rats were sacrificed painlessly and blood was collected through cardiac puncture from each rat into EDTA and heparin sample bottles. The anti-coagulated blood in EDTA sample bottles was centrifuged at $1000 \mathrm{rpm}$ for 10 minutes to obtain plasma that was used for the analysis on renal parameters while the anti-coagulated blood in heparin sample bottles was used for hematological analysis.

\subsection{Determination of Kidney Function Parameters}

Creatinine was determined using the method of [22], calcium ion, sodium ion and potassium ion were assayed according to the method of [23], Chloride ion was carried out using the method of [24] while magnesium ion was determined using the method of [25].

Table 1. Procedure for Dosage administration

\begin{tabular}{|c|c|}
\hline Group & Treatment \\
\hline I (normal control) & Received normal feed and water daily \\
\hline II $\left(\mathrm{CCl}_{4}\right)$ & Received subcutaneous dose of $\mathrm{CCl}_{4}(0.17 \mathrm{~mL} / \mathrm{kgbw})$ on the first day only \\
\hline III (olive oil) & Received olive oil on the first day only \\
\hline IV (50 mg/kgbw) & $\begin{array}{l}\text { Received subcutaneous dose of } \mathrm{CCl}_{4}(0.17 \mathrm{~mL} / \mathrm{kgbw}) \text { on the first day }+ \text { oral dose of } C \text {. } \\
\text { aconitifolius extract }(50 \mathrm{mg} / \mathrm{kgbw}) \text { daily for } 21 \text { days }\end{array}$ \\
\hline $\mathrm{V}(75 \mathrm{mg} / \mathrm{kgbw})$ & $\begin{array}{l}\text { Received subcutaneous dose of } \mathrm{CCl}_{4}(0.17 \mathrm{~mL} / \mathrm{kgbw}) \text { on the first day }+ \text { oral dose of } C \text {. } \\
\text { aconitifolius extract }(75 \mathrm{mg} / \mathrm{kgbw}) \text { daily for } 21 \text { days }\end{array}$ \\
\hline VI (100 mg/kgbw) & $\begin{array}{l}\text { Received subcutaneous dose of } \mathrm{CCl}_{4}(0.17 \mathrm{~mL} / \mathrm{kgbw}) \text { on the first day }+ \text { oral dose of } C \text {. } \\
\text { aconitifolius extract }(100 \mathrm{mg} / \mathrm{kgbw}) \text { daily for } 21 \text { days }\end{array}$ \\
\hline VII (Vitamin C) & $\begin{array}{l}\text { Received subcutaneous dose of } \mathrm{CCl}_{4}(0.17 \mathrm{~mL} / \mathrm{kgbw}) \text { on the first day + oral dose of Vit. C daily } \\
\text { for } 21 \text { days }\end{array}$ \\
\hline
\end{tabular}

\section{Results}

\subsection{Effect of Cnidoscolus aconitifolius Leaf Extract on the Kidney Function Parameters}

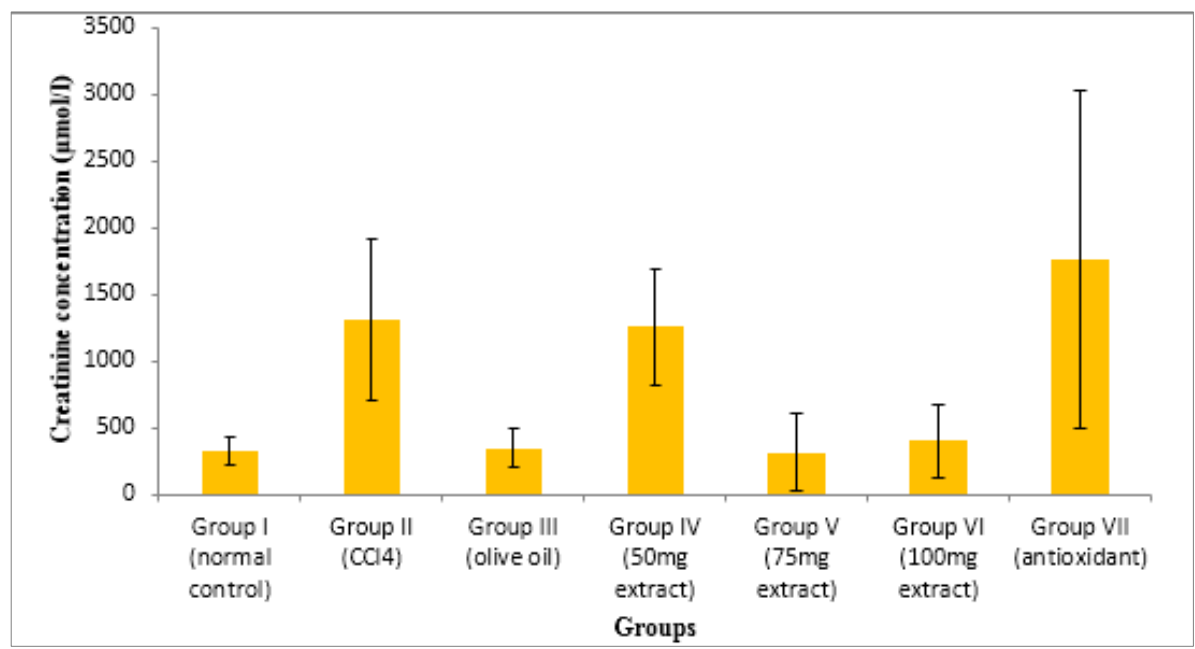

Values are mean \pm S.D, $\mathrm{n}=6$ per group. There was no significant difference at $\mathrm{P}<0.05$ across all the groups.

Figure 1. Ameliorative effect of the leaf extract of C. aconitifolius on creatinine concentration of $\mathrm{CCl}_{4}$ treated wistar rats 


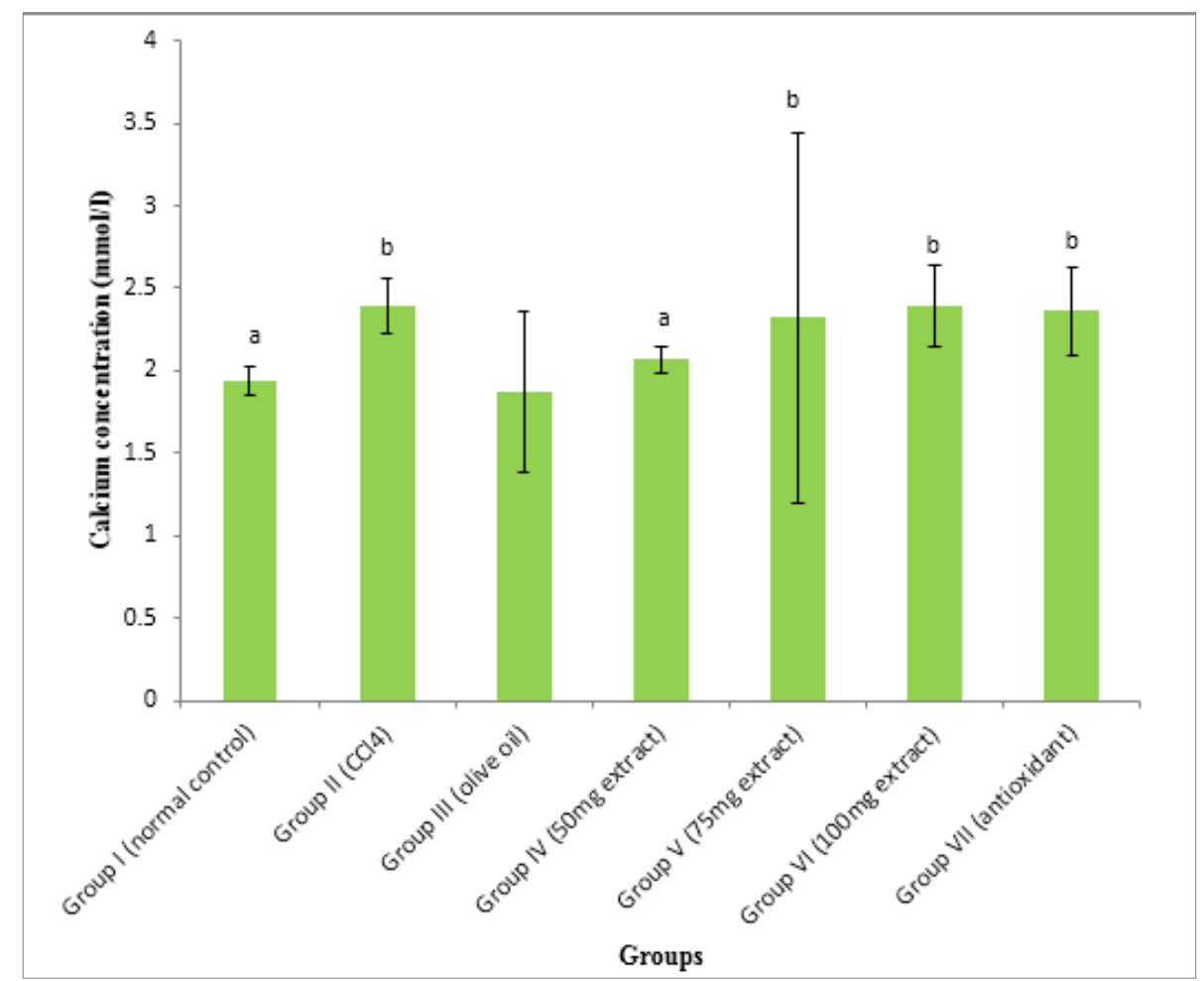

Values are mean \pm S.D, $n=6$ per group. Bars bearing different superscript letters (a, b) are significantly different at $\mathrm{P}<0.05$ when compared to groups I and II respectively.

Figure 2. Ameliorative effect of the leaf extract of C. aconitifolius on calcium concentration of $\mathrm{CCl}_{4}$ treated wistar rats

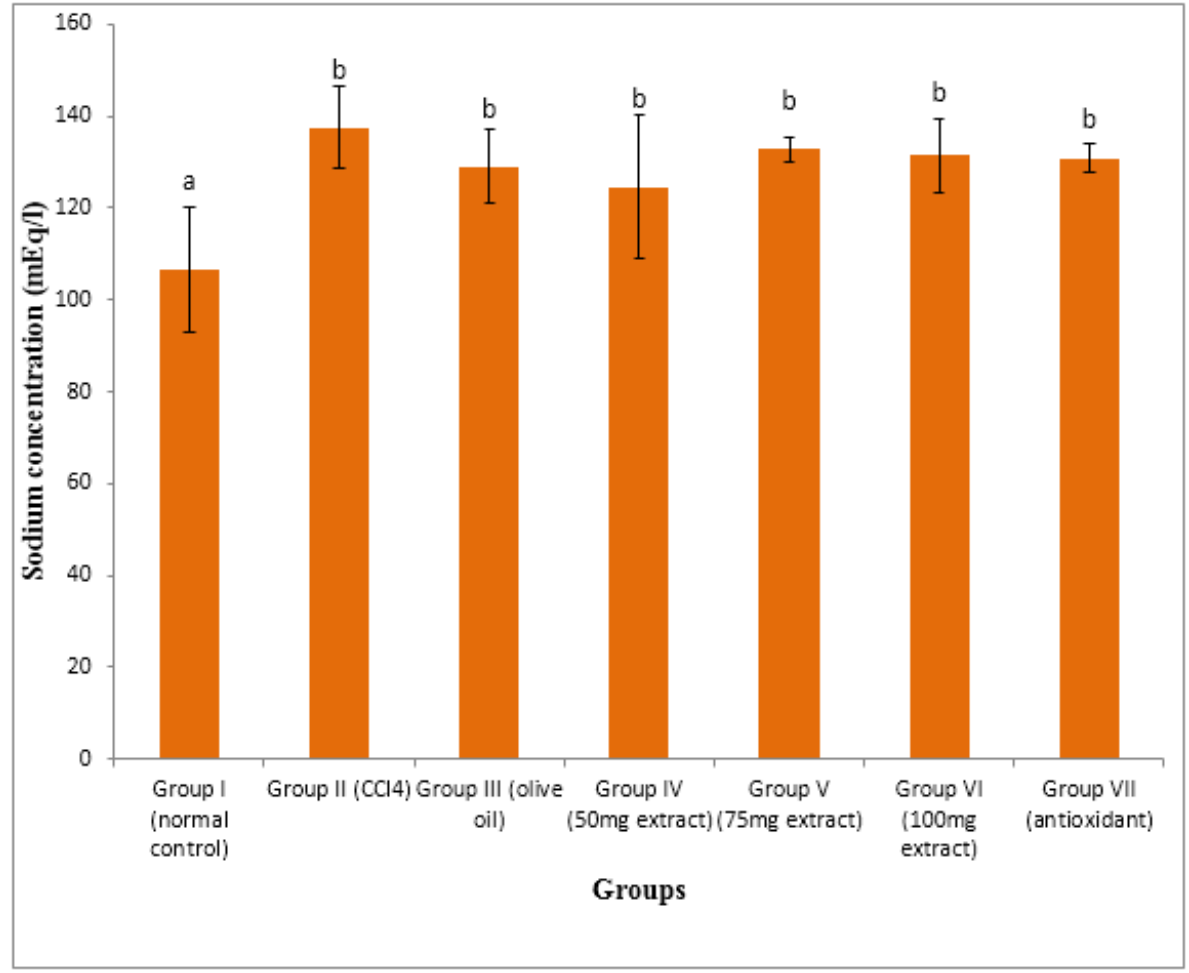

Values are mean \pm S.D, $\mathrm{n}=6$ per group. Bars bearing different superscript letters ( $\mathrm{a}, \mathrm{b}$ ) are significantly different at $\mathrm{P}<0.05$ when compared to groups I and II respectively.

Figure 3. Ameliorative effect of the leaf extract of C. aconitifolius on sodium concentration of $\mathrm{CCl}_{4}$ treated wistar rats 


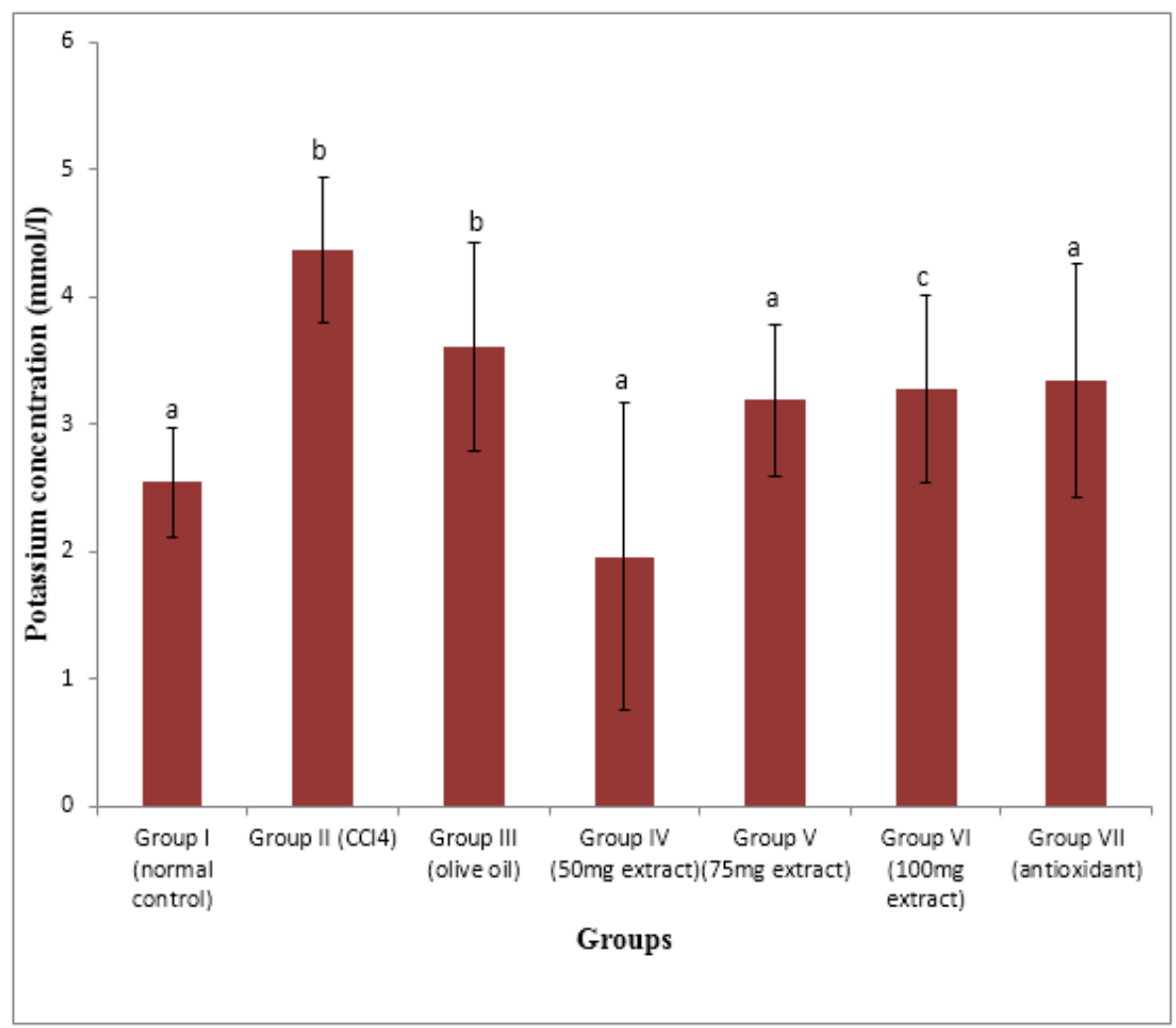

Values are mean \pm S.D, $\mathrm{n}=6$ per group. Bars bearing different superscript letters ( $\mathrm{a}, \mathrm{b}, \mathrm{c}$ ) are significantly different at $\mathrm{P}<0.05$ when compared to groups I and II respectively.

Figure 4. Ameliorative effect of the leaf extract of C. aconitifolius on potassium concentration of $\mathrm{CCl}_{4}$ treated wistar rats

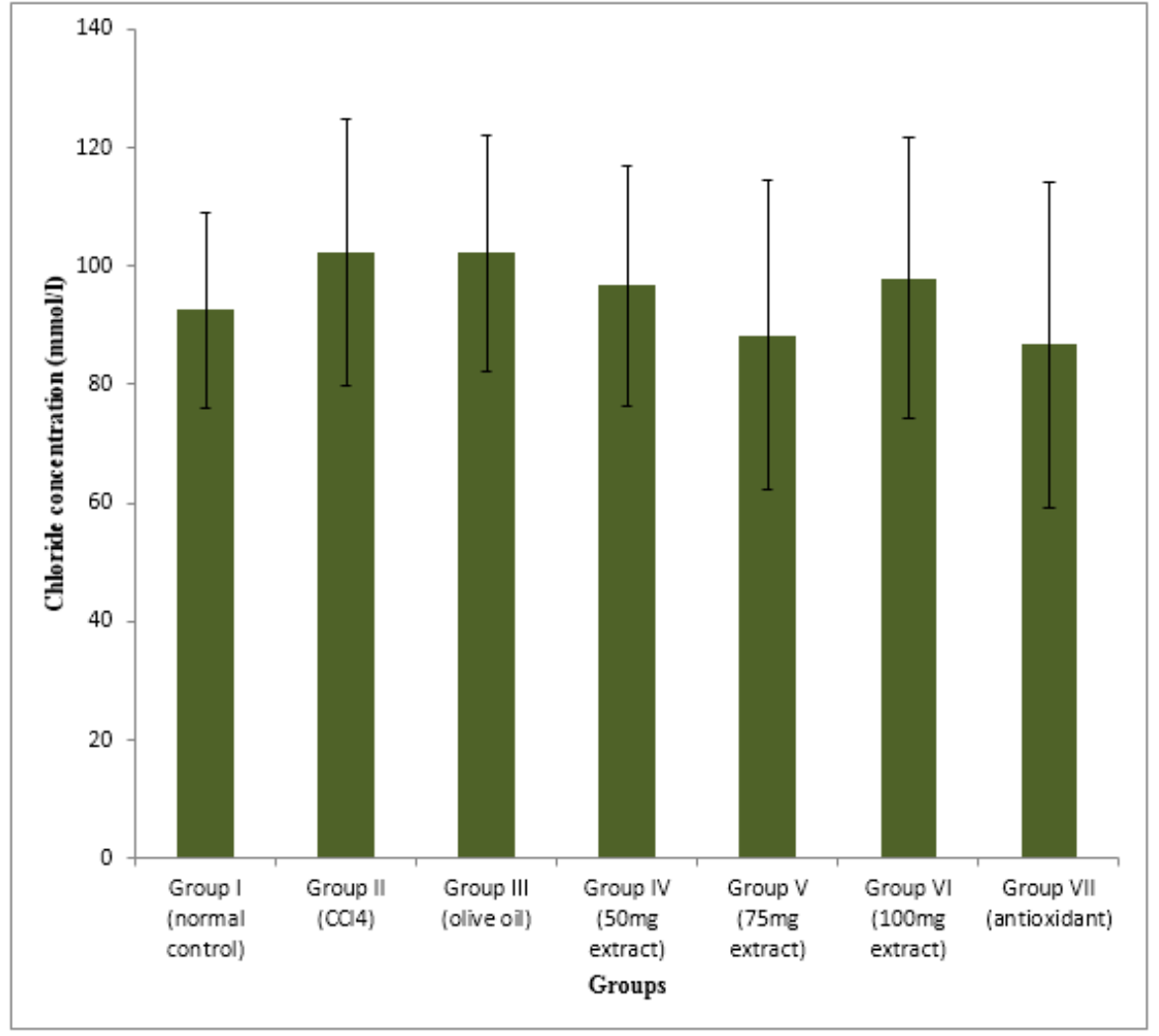

Values are mean \pm S.D, $\mathrm{n}=6$ per group. There was no significant difference at $\mathrm{P}<0.05$ across all the groups.

Figure 5. Ameliorative effect of the leaf extract of $C$. aconitifolius on chloride concentration of $\mathrm{CCl}_{4}$ treated wistar rats 


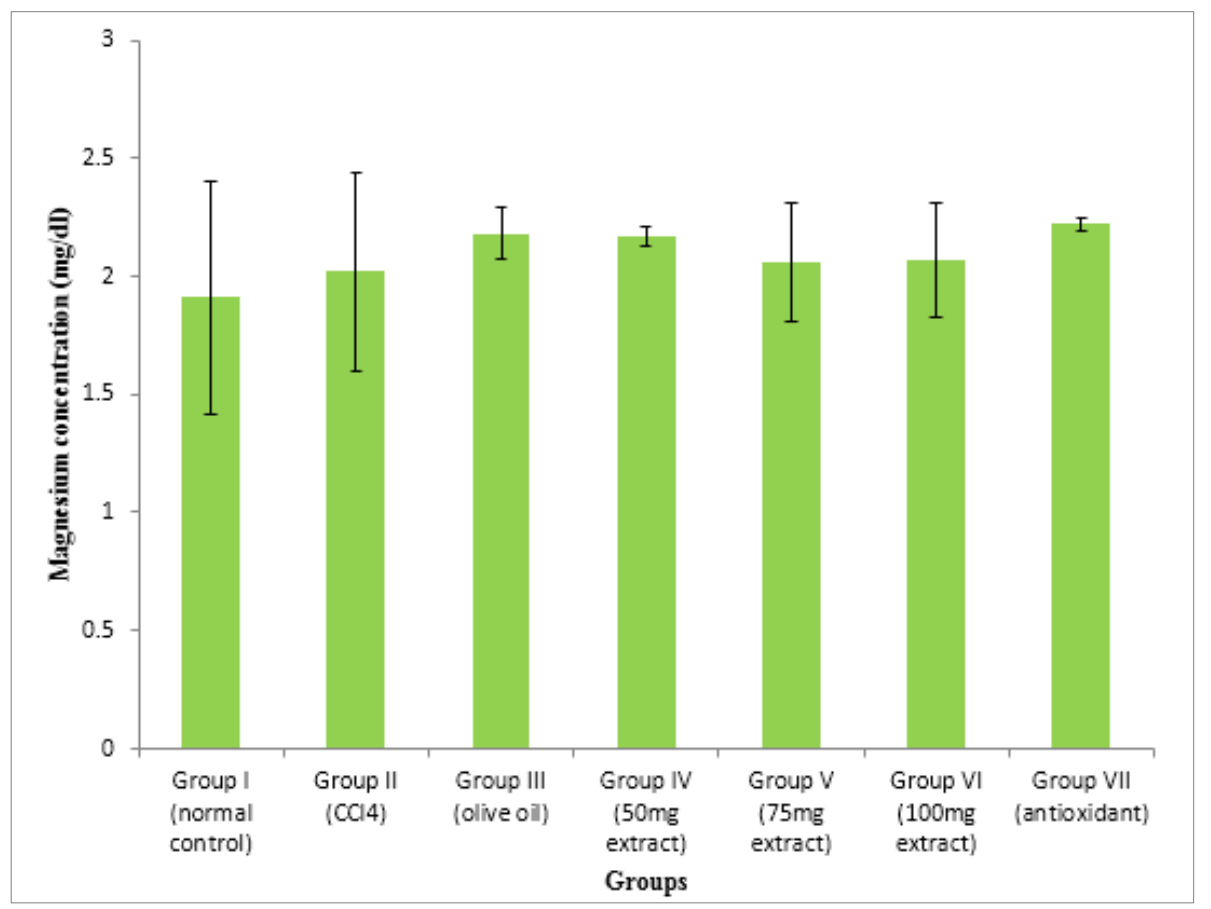

Values are mean \pm S.D, $\mathrm{n}=6$ per group. There was no significant difference at $\mathrm{P}<0.05$ across all the groups.

Figure 6. Ameliorative effect of the leaf extract of C. aconitifolius on magnesium concentration of $\mathrm{CCl}_{4}$ treated wistar rats

Table 2. Effect of the Leaf Extract of Cnidoscolus aconitifolius on Hematological Parameters

\begin{tabular}{|c|c|c|c|c|c|c|c|}
\hline Parameters & $\begin{array}{l}\text { Group I } \\
\text { (normal } \\
\text { control) }\end{array}$ & $\begin{array}{c}\text { Group II } \\
\left(\mathrm{CCl}_{4}\right)\end{array}$ & $\begin{array}{l}\text { Group III } \\
\text { (olive oil) }\end{array}$ & $\begin{array}{c}\text { Group IV } \\
\text { (50mg/kgbw } \\
\text { extract) }\end{array}$ & $\begin{array}{c}\text { Group V } \\
\text { (75mg/kgbw } \\
\text { extract) }\end{array}$ & $\begin{array}{c}\text { Group VI } \\
\text { (100mg/kgbw } \\
\text { extract) }\end{array}$ & $\begin{array}{c}\text { Group VII } \\
\text { (vitamin C) }\end{array}$ \\
\hline $\begin{array}{c}\mathrm{RBC} \\
\left(10^{12} / \mathrm{L}\right)\end{array}$ & $7.15 \pm 0.54^{\mathrm{a}}$ & $5.54 \pm 1.13^{\mathrm{b}}$ & $6.87 \pm 1.24$ & $7.83 \pm 0.57^{\mathrm{a}}$ & $7.14 \pm 0.93^{\mathrm{a}}$ & $7.63 \pm 0.49^{\mathrm{a}}$ & $7.65 \pm 1.11^{\mathrm{a}}$ \\
\hline $\begin{array}{l}\text { WBC } \\
\left(10^{9} / \mathrm{L}\right)\end{array}$ & $5.14 \pm 1.71$ & $4.05 \pm 1.42$ & $4.53 \pm 1.74$ & $4.30 \pm 0.99$ & $4.27 \pm 0.88$ & $3.83 \pm 1.09$ & $6.15 \pm 2.04$ \\
\hline $\mathrm{Hb}(\mathrm{g} / \mathrm{dl})$ & $13.40 \pm 0.97^{\mathrm{a}}$ & $10.78 \pm 0.85^{\mathrm{b}}$ & $13.02 \pm 0.88^{\mathrm{a}}$ & $14.43 \pm 0.92^{\mathrm{c}}$ & $13.47 \pm 1.43^{\mathrm{a}}$ & $14.25 \pm 1.12^{\mathrm{c}}$ & $14.07 \pm 1.91$ \\
\hline PCV (\%) & $39.10 \pm 3.28^{\mathrm{a}}$ & $30.83 \pm 6.31^{\mathrm{b}}$ & $37.58 \pm 6.91$ & $40.95 \pm 2.29^{c}$ & $37.87 \pm 4.32^{\mathrm{a}}$ & $41.88 \pm 3.45^{\mathrm{c}}$ & $39.73 \pm 5.11$ \\
\hline MCV (fl) & $54.68 \pm 2.62^{\mathrm{a}}$ & $54.83 \pm 1.78^{\mathrm{a}}$ & $54.70 \pm 0.98$ & $52.48 \pm 1.35^{\mathrm{b}}$ & $53.18 \pm 1.95^{\mathrm{a}}$ & $55.68 \pm 1.95^{\mathrm{a}}$ & $52.10 \pm 1.99^{\mathrm{b}}$ \\
\hline MCH (pg) & $18.80 \pm 0.79^{\mathrm{a}}$ & $18.68 \pm 0.42^{\mathrm{a}}$ & $19.02 \pm 0.89$ & $18.47 \pm 0.30^{\mathrm{a}}$ & $18.95 \pm 0.70^{\mathrm{a}}$ & $19.50 \pm 0.89^{b}$ & $18.43 \pm 0.50^{\mathrm{a}}$ \\
\hline $\begin{array}{c}\text { MCHC } \\
(\mathrm{g} / \mathrm{dl})\end{array}$ & $34.40 \pm 0.67^{\mathrm{a}}$ & $34.08 \pm 0.53^{\mathrm{a}}$ & $34.80 \pm 1.25$ & $34.85 \pm 0.56^{\mathrm{a}}$ & $35.63 \pm 0.54^{\mathrm{b}}$ & $35.07 \pm 1.38^{\mathrm{a}}$ & $34.93 \pm 2.26^{\mathrm{a}}$ \\
\hline $\operatorname{Lym}\left(10^{9} / \mathrm{L}\right)$ & $3.44 \pm 2.04$ & $2.60 \pm 1.23$ & $2.73 \pm 1.73$ & $3.35 \pm 1.85$ & $2.43 \pm 1.58$ & $3.13 \pm 1.08$ & $4.27 \pm 1.77$ \\
\hline MPV (fL) & $6.08 \pm 0.38^{\mathrm{a}}$ & $6.10 \pm 0.25^{\mathrm{a}}$ & $6.10 \pm 0.17$ & $6.02 \pm 0.21^{\mathrm{a}}$ & $6.17 \pm 0.30^{\mathrm{a}}$ & $6.50 \pm 0.24^{\mathrm{b}}$ & $6.28 \pm 0.19^{\mathrm{a}}$ \\
\hline RDW (\%) & $16.90 \pm 0.66^{\mathrm{a}}$ & $17.68 \pm 1.23^{\mathrm{a}}$ & $16.30 \pm 1.45^{\mathrm{b}}$ & $17.68 \pm 1.01^{\mathrm{a}}$ & $17.12 \pm 1.14^{\mathrm{a}}$ & $15.45 \pm 0.58^{\mathrm{b}}$ & $16.90 \pm 1.12^{\mathrm{a}}$ \\
\hline PDW (\%) & $9.46 \pm 0.55^{\mathrm{a}}$ & $9.37 \pm 0.32^{\mathrm{a}}$ & $9.37 \pm 0.23$ & $9.31 \pm 0.31^{\mathrm{a}}$ & $9.53 \pm 0.49^{a}$ & $9.95 \pm 0.37^{b}$ & $9.62 \pm 0.26^{\mathrm{a}}$ \\
\hline $\begin{array}{c}\text { Platelets } \\
\left(10^{9} / \mathrm{L}\right)\end{array}$ & $289.60 \pm 55.76^{\mathrm{a}}$ & $229.33 \pm 49.23^{b}$ & $362.00 \pm 70.84$ & $508.83 \pm 62.04^{c}$ & $387.50 \pm 89.28^{c}$ & $404.17 \pm 69.44^{c}$ & $385.33 \pm 100.98^{c}$ \\
\hline РCТ (\%) & $0.17 \pm 0.09^{\mathrm{a}}$ & $0.24 \pm 0.10^{\mathrm{a}}$ & $0.22 \pm 0.10^{\mathrm{a}}$ & $0.30 \pm 0.09^{b}$ & $0.24 \pm 0.14^{\mathrm{a}}$ & $0.15 \pm 0.08^{\mathrm{a}}$ & $0.24 \pm 0.15^{\mathrm{a}}$ \\
\hline
\end{tabular}

Values are mean \pm S.D, $n=6$ per group. Values bearing different superscript letters (a, b, c) are significantly different at $\mathrm{P}<0.05$ when compared to groups I and II respectively.

KEY: RBC-red blood cell, WBC- white blood cell, Hb- haemaglobin, PCV- packed cell volume, MCV- mean cell volume, MCH- mean cell haemoglobin, MCHC- mean cell haemoglobin concentration, Lym- lymphocytes, MPV- mean platelet volume, RDW- red cell distribution width, PDW- platelet distribution width, PCT- plateletcrit 


\section{Discussion}

Figure 1-6 shows the effect of the leaf extract of $C$. aconitifolius on kidney parameters of $\mathrm{CCl}_{4}$ treated wistar rats. Creatinine is a renal function index that helps determine the functional status of the nephron [26]. This study showed that plasma creatinine concentration increased slightly in $\mathrm{CCl}_{4}$ treated rats but were ameliorated with the extract of $C$. aconitifolius leaf at $75 \mathrm{mg} / \mathrm{kg}$ body weight and $100 \mathrm{mg} / \mathrm{kg}$ body weight.

There was no significant difference in the chloride and magnesium electrolyte levels in all the compared groups (Figure 5 and 6). There was a significant increase $(\mathrm{P}<0.05)$ in the calcium levels of $\mathrm{CCl}_{4}$ treated rats and rats administered with the leaf extract at $75 \mathrm{mg} / \mathrm{kg}$ and 100 $\mathrm{mg} / \mathrm{kg}$ when compared with the normal. This was however, reduced significantly $(\mathrm{P}<0.05)$ by the extract at $50 \mathrm{mg} / \mathrm{kg}$ body weight (Figure 2). There was a significant increase $(\mathrm{P}<0.05)$ in the sodium level of $\mathrm{CCl}_{4}$ treated rats (Figure 3) but were decreased by administration of the leaf extract of C. aconitifolius.

Also, there was a significant increase $(\mathrm{P}<0.05)$ in the potassium levels of $\mathrm{CCl}_{4}$ treated rats (Figure 4) but this was decreased by the administration of the leaf extract of $C$. aconitifolius in a dose dependent manner. The increase in calcium, sodium and potassium levels might be from olive oil as shown by their increase $(\mathrm{P}<0.05)$ in the rats administered with olive oil when compared to the normal control (Figures 2, 3 and 4). Olive oil served as a vehicle to convey $\mathrm{CCl}_{4}$ into the blood stream of the rats. This study further agrees with earlier studies by [27], [28] and [29], on hepatoprotective activity, anti-hepatotoxic and antioxidant defense potential and alteration of plasma biochemical, haematological and ocular oxidative indices of Tridax procumbens plant extracts respectively. According to [30] and [31], the concentration of calcium ion in body fluids and its handling by cellular proteins are disturbed. The extract reversed the effect of $\mathrm{CCl}_{4}$ toxicity by lowering the plasma calcium, sodium and potassium levels. It significantly $(\mathrm{P}<0.05)$ lowered the calcium levels at 50 $\mathrm{mg} / \mathrm{kgbw}$ and potassium levels all extract dose administered. Similar observations were made by [32] in their research on plasma electrolytes in sub-chronic salt-loaded rats by aqueous leaf extract of Tridax procumbens linn. Calcium fluxes helps in cushioning hormonal effect on target organs via numerous intracellular pathways and neuromuscular activities [33, 34]. C. aconitifolius leaf extract might have exerted this effect through its action on the secretion of parathyroid hormone. This hormone facilitates intestinal calcium absorption by encouraging the renal production of 1, 2, 5 dihydroxy vitamin $\mathrm{D}$ and in the process, increasing re-absorption of calcium in the renal tubule [32]. Invariably, results obtained in this study showed that $C$. aconitifolius leaf extract at various doses independently enhanced kidney function especially at lower doses.
Anti-hypertensive drugs especially diuretics act by decreasing the plasma chloride and sodium electrolytes through slowing their reabsorption at different points in the nephrons [35, 34]. Results of this study showed that there was no significant change in the chloride concentration while sodium; there was a significant decrease in the rats administered with the leaf extract. This implies that $C$. aconitifolius leaf extract may be used as anti-hypertensive drug.

The effect of $\mathrm{CCl}_{4}$ treated rats administered with the leaf extract of $C$. aconitifolius on hematological indices is represented in Table 2. There were no significant differences $(\mathrm{P}<0.05)$ in the total white blood cell (WBC) count and lymphocytes count of treated rats when compared to $\mathrm{CCl}_{4}$ and normal control groups. There was a significant increase in the red blood cell (RBC) count, packed cell volume (PCV), haemaglobin ( $\mathrm{Hb})$ and platelet number of rats administered with $C$. aconitifolius leaf extract at all doses when compared to $\mathrm{CCl}_{4}$ group. The plant extract enhanced the RBC count better at $50 \mathrm{mg} / \mathrm{kg}$, followed by $100 \mathrm{mg} / \mathrm{kg}$ and then $75 \mathrm{mg} / \mathrm{kg}$ body weights. The mean cell volume of rats administered with $50 \mathrm{mg} / \mathrm{kg}$ body weight leaf extract was significantly lower $(\mathrm{P}<0.05)$ than $\mathrm{CCl}_{4}$ and normal control groups. The mean cell haemoglobin $(\mathrm{MCH})$ of rats administered with $100 \mathrm{mg} / \mathrm{kg}$ body weight extract was significantly higher $(\mathrm{P}<0.05)$ than $\mathrm{CCl}_{4}$ treated rats while the mean cell haemoglobin concentration (MCHC) of rats administered withC. aconitifolius at all extract doses were higher but significantly higher $(\mathrm{P}<0.05)$ at $75 \mathrm{mg} / \mathrm{kg}$ body weight than $\mathrm{CCl}_{4}$ treated group. Also, the mean platelet volume (MPV) of rats administered with $100 \mathrm{mg} / \mathrm{kg}$ body weight extract was significantly higher $(\mathrm{P}<0.05)$ than $\mathrm{CCl}_{4}$ and normal control groups. The red cell distribution width (RDW) of rats administered with $50 \mathrm{mg} / \mathrm{kg}$ body weight leaf extract was the same as $\mathrm{CCl}_{4}$, but lower with the extract at 75 $\mathrm{mg} / \mathrm{kg}$ body weight, while the group administered with 100 $\mathrm{mg} / \mathrm{kg}$ body weight extract was significantly lower $(\mathrm{P}<0.05)$ than $\mathrm{CCl}_{4}$ and normal control groups. The platelet distribution width (PDW) of rats administered with 100 $\mathrm{mg} / \mathrm{kg}$ body weight extract was significantly higher $(\mathrm{P}<0.05)$ than $\mathrm{CCl}_{4}$ and normal control groups. The platelet crit (PCT) level of rats administered with $75 \mathrm{mg} / \mathrm{kg}$ body weight extract was the same as $\mathrm{CCl}_{4}$ group.

The result of the study showed that the extract had a positive effect that was dose dependent on the haemopoietic system of the test rats. It increased significantly the red blood cell count, haemoglobin, packed cell volume and platelet count at all extract doses, mean cell haemoglobin at $100 \mathrm{mg} / \mathrm{kg}$ body weight extract dose and mean cell haemoglobin concentrations at $75 \mathrm{mg} / \mathrm{kg}$ body weight extract dose. According to some researchers [36, 37, 38, 39], WBC help in destabilizing plaques in the coronary artery during the early stages of acute coronary syndrome. Nevertheless, increased white blood cell count is a sign of coronary artery disease in the peripheral blood 
[39]. Results obtained here showed that there was no significant change in the WBC and lymphocytes count which indicates that the immune systems of the rats were not compromised by the extract. Results of this study is similar to findings of [40] and [29] on his works on "moderation of hematological and plasma biochemical indices of subchronic salt-loaded rats, by an aqueous extract of the leaves of Acalypha wilkesiana" and "alteration of plasma biochemical, haematological and ocular oxidative indices of alloxan induced diabetic rats by aqueous extract of Tridax procumbens linn” respectively.

\section{Conclusions}

The present study has shown that the leaf extract of Cnidoscolus aconitifolius had a dose-dependent positive effect on the hematological indices as well as the potential to ameliorate kidney parameters of $\mathrm{CCl}_{4}$ treated wistar rats at the given concentrations. It significantly decreased the calcium levels at $50 \mathrm{mg} / \mathrm{kg}$ body weight and potassium levels at all extract doses administered thereby enhancing the cushioning effect and increasing their re-absorption.

\section{REFERENCES}

[1] Prabakaran, A.J. and Sujatha, M. (1999). Jatropha tanjorensis Ellis and Saroja, a natural inter-specific hybrid occurring in Tamil Nadu, India. Genetic Resources and Crop Evolution, 46, 213-218.

[2] Omoregie, E.S and Osagie, A.U. (2012). Antioxidant properties of methanolic extracts of some Nigerian plants on nutritionally- stressed rats. Nigerian Journal of Basic and Applied Science, 20(1), 7-20.

[3] Ezeonu, D.O., Anosike, C.A. And Njoku, O.U. (2017). Hepatoprotective and Antioxidant Effects of the Flavonoid-rich Fraction of the Methanol Extract of Jatropha tanjorensis Leaves in $\mathrm{CCl}_{4}$-induced Liver Injury in Rats. Journal of Pharmacy and Biological Sciences, 12(1), 54-61.

[4] Oboh, F.O.J. and Masodje, H.I. (2009). Nutritional and antimicrobial properties of Cnidoscolus aconitifolius leaves. America-Eurasian Journal of Scientific Research, 4(1), 7-10.

[5] Iwalewa, E.O., Adewunmi, C.O., Omisore, N.O., Adebanji, O.A. and Azike, C.K. (2005). Pro and antioxidant effects and cytoprotective potentials of nine edible vegetables in southwest Nigeria. Journal of Medicinal Food, 8, 539-544.

[6] Oduola, T., Avwioro, O.G. and Ayanniyi, T.B. (2005). Suitability of the leaf extract of Jatropha gossipif oliaasan anticoa gulant for biochemical and haematological analysis. African Journal of Biotechnology, 4, 679-681.

[7] Aye, P.A. (2012). Effect of processing on the nutritive characteristics, anti-nutritional factors and functional properties of Cnidoscolus aconitifolius leaves (Iyana Ipaja).
American Journal of Food and Nutrition, 2 (4), 89-95.

[8] Levander, O.A. (1990). Fruit and vegetable contribution to dietary mineral intake in human health and disease. HortScience, 25, 1486-1488.

[9] Kuti, J.O. and Torres, E.S. (1996). Potential nutritional and health benefits of the spinach: In J. Jarick (ed). Progress innew crops. ASHS Press, Arlington, VA. pp. 516-520.

[10] Adanlawo, I.G. and Elekofehinti, O.O. (2012). Proximate analysis, mineral composition and amino acid composition of Cnidoscolus aconitifolius leaf. Advances in Food and Energy Security, 2, 17-21.

[11] Oyagbemi, A. A., Odetola, A. A. and Azeez, O. I. (2008). Ameliorative effects of Cnidoscolus aconitifolius on anaemia and osmotic fragility induced by protein energy malnutrition. African Journal of Biotechnology, 7(11), 1721-1726.

[12] Yang, Y. H. (1979). Tropical home gardens as a nutritional intervention. In: Inglett, G. E. and Charalambous, G. (eds.), Tropical food chemistry and nutrition, Academic Press, New York. pp. 417-436.

[13] Shankar, A.H. and Prasad, A.S. (1998). Zinc and immunefunction: The biological basis of altered resistance to infection. American Journal of Clinical Nutrition, 68, 4478-4463.

[14] Muller, O., Becher, H., VanZweeden, A.B.Y.Y., Diallo, D.A., Konate, A.T., Gbangou, A., Kouyate, B. and Garenne, M. (2001). Effect of zinc supplementation on malaria and other causes of morbidity in West African children: Randomized double blind placebo controlled trial. British Medical Journal, 322(7302), 1567-7150.

[15] Garba, I.H., Ubom, G.A. and Haruna, M. (2002). Falciparum Malaria infection is associated with increased Mobilization of Tissue Stores of Ascorbic Acid: Evidence that Ascorbate Plays a Significant Role in the Acute Onset of this Disease. Informedia (2002). Paving the way to the global e-Health. $2^{\text {nd }}$ Ibero American Congress of Medical Informatics on the Internet. Nov. 4 -30th. 2002 on the Internet.

[16] Duggen, C., Macleod, W. B., Krebs, N. F., Westcott, J. L., Fawzi, W. W., Premji, Z. G., Mwanakasale. V., Simon, J. L., Yeboah-Antwi, K. and Kamer, D. H., (2005). The Zn against Plasmodium study group: Plasma Zinc concentrations are depressed during the acute phase response in children with Falciparum Malaria. Journal of Nutrition, 138, 802-807.

[17] Berkelaar, D. (2006). Chaya. Echo Technical Note.www.echonet.org

[18] Sofowara, A. (2008). Medicinal plants and traditional medicine in Africa. ${ }^{\text {rd }}$ Edition. pp. 196-203.

[19] Obi, F.O. and Uneh, E. (2003). pH dependent prevention of carbon tetrachloride-induced lipoperioxidation in rats by ethanolic extract of Hibiscus rosasinensis petal. Biokemistri, 13, 42-50.

[20] Ikewuchi, J.C. and Ikewuchi, C.C. (2010). Hypocholesterolaemic effect of aqueous extract of Acalyphawilkesiana 'Godseffiana' Muell Argon rats fed egg yolk supplemented diet: Implications for cardiovascular risk management. Research Journal of Science and 
Technology,2(4), 78-81.

[21] Ikewuchi, J.C. (2010). Changes in the weight, plasma lipid profile, and atherogenic indices of salt-loaded rats by aqueous extract of Acalypha wilkesiana Muell Arg: Potential for cardiovascular risk reduction. Pacific Journal of Science and Technology, 11, 516-523.

[22] Bartels, H. and Bolmer, M. (1971). Micro-determination of creatinine. Clinica Chimica Acta, 32(1), 81-85.

[23] Henry, R.F. (1974). Clinical Chemistry Principle and Techniques. $2^{\text {nd }}$ edition.

[24] Young, D.S. (1995). Effects of drugs on clinical lab tests. $4^{\text {th }}$ ad AACC press.

[25] Young, D.S. (2001). Effects of disease on clinical lab tests. $4^{\text {th }}$ edn AACC press.

[26] Akachukwu, D., Okafor, P.N. and Ibegbulem, C.O. (2014). Phytochemical content of Cnidoscolus aconitifolius and toxicological effect of its aqueous leaf extract in wistar rats. Journal of Investigational Biochemistry, 1(1), 26-31.

[27] Ravikumar, V., Shivashangari, K.S. and Devaki, T. (2005). Hepatoprotective activity of Tridax procumbens against d-galactosamine/lipopolysaccharide-induced hepatitis in rats. Journal of Ethnopharmacology, 101(1-3), 55-60.

[28] Hemalatha, R. (2008). Anti-hepatotoxic and antioxidant defense potential of Tridax procumbens. International Journal of Green Pharmacy, 2(3), 164-169.

[29] Ikewuchi, J.C. (2012). Alteration of plasma biochemical, haematological and ocular oxidative indices of alloxan induced diabetic rats by aqueous extract of Tridax procumbens linn (Asteraceae). EXCLI Journal, 11, 291-308.

[30] McCarron, D.A. (1982). Low serum concentrations of ionized calcium in patients with hypertension. New England Journal of Medicine, 309, 226-228.

[31] Young, E.W., Bukoski, R.D. and McCarron, D.A. (1988). Calcium metabolism in experimental hypertension. Proceedings in Social Experimental Biology and Medicine, 187, 123-141.

[32] Ikewuchi, J.C. and Ikewuchi, C.C. (2013).Moderation of haematological indices, plasma electrolytes and markers of hepato-renal function in sub-chronic salt-loaded rats by an aqueous leaf extract of Tridax procumbens Linn (Asteraceae). Pacific Journal of Science and Technology, 14(1), 362-369.

[33] Food Agriculture Organization (2004). Vitamin and mineral requirements in human nutrition (2nd edition). A report of a Joint FAO/WHO Expert Consultation, Bangkok, Thailand. ISBN 9241546123.

[34] Crook, M.A. (2006). Clinical chemistry and metabolic medicine. 7th edition. Holder Arnold. London, UK.

[35] Rang, H.P., Dale, M.M., Ritter, J.M. and Moore, P.K. (2005). Pharmacology. 5th edition. Elsevier: India.

[36] Moreno, P.R., Falk, E., Palacios, I.F., Newell, J.B., Fuster, V. and Fallon, J.T. (1994). Macrophage infiltration in acute coronary syndromes: Implications for plaque rupture. Circulation, 90(2), 775-778.
[37] van der Wal, A.C., Becker, A.E., van der Loos, C.M. and Das, P.K. (1994). Site of intimal rupture or erosion of thrombosed coronary atherosclerotic plaques is characterized by an inflammatory process irrespective of the dominant plaque morphology. Circulation, 89(1), 36-44.

[38] Libby, P. (2001). Current concepts of the pathogenesis of the acute coronary syndromes. Circulation, 104(3), 365-372.

[39] Takeda, Y., Suzuki, S., Fukutomi, T., Kondo, H., Sugiura, M. and Suzumura, H. (2013). Elevated white blood cell count as a risk factor of coronary artery disease: Inconsistency between forms of the disease. Japanese Heart Journal, 44(2), 201-211.

[40] Ikewuchi, J.C. (2013). Moderation of hematological and plasma biochemical indices of subchronic salt-loaded rats, by an aqueous extract of the leaves of Acalypha wilkesiana 'Godseffiana' Muell Arg (Euphorbiaceae). Asian Pacific Journal of Tropical Medicine, 1, 37-42. 